\title{
Hábitos de luta: freiras, contestação e ditadura no Brasil
}

\author{
Caroline Jaques Cubas ${ }^{1^{*}}$ \\ ${ }^{1}$ Universidade do Estado de Santa Catarina, Florianópolis/SC - Brasil
}

\section{RESUMO}

Este artigo ${ }^{1}$ analisa o envolvimento de religiosas em movimentos de oposição ou resistência à ditadura brasileira. A presente reflexão é impulsionada pela constatação de que os trabalhos que se referem às relaçôes entre Igreja e ditadura tratam majoritariamente das açôes de padres e bispos, delegando às religiosas um papel secundário e raramente detalhado. Para tanto, nos dedicamos especificamente à observação da forma como tal participaçáo foi retratada por jornais impressos de grande circulação no período em questão. Priorizando reportagens publicadas nos anos 1967 e 1968, nosso intuito é problematizar a participaçáo efetiva de religiosas em passeatas e manifestaçóes, assim como o espaço dessa participação na historiografia contemporânea. Este artigo ampara-se nas discussôes de Jacques Semelin sobre a noção de resistência e na categoria de gênero.

Palavras-chave: vida religiosa feminina; freiras; Igreja Católica; passeatas; ditadura.

\section{Fighting Habits: nuns, protest, and dictatorship in Brazil}

\section{ABSTRACT}

This article analyzes the involvement of nuns in movements of opposition and resistance to the Brazilian dictatorship. This reflection is motivated by the fact that most studies that discuss the relationship between the Church and dictatorship deal mainly with the actions of priests and bishops, relegating nuns to a secondary role and rarely discussing them in detail. This study aims to explore the role of nuns in the fight against dictatorship by looking at how popular newspapers of the time-especially those from 1967 and 1968—characterized their actions. Our intention is to explore the effective participation of nuns in marches and

DOI: http://dx.doi.org/10.1590/2237-101X02104408

Artigo recebido em 21 de janeiro de 2019 e aceito para publicação em 30 de setembro de 2019.

* Professora da Universidade do Estado de Santa Catarina / Departamento de História, Florianópolis/SC Brasil. E-mail: caroljcubas@gmail.com. ORCID: https://orcid.org/0000-0001-5411-6824.

${ }^{1}$ A presente publicação vincula-se aos grupos de pesquisa "Ensino de História, memória e culturas" e "Linguagens e representação", que contam com recursos da FAPESC. 
protests as well as the space of this participation in contemporary historiography. This article builds on Jacques Sémelin's work on resistance and gender.

Keywords: female religious life; nuns; Catholic Church; marches; dictatorship.

\section{Hábitos de lucha: monjas, protestas y dictadura en el Brasil}

\section{RESUMEN}

Este artículo analiza el envolvimiento de religiosas en movimientos de oposición o resistencia a la dictadura brasileña. La presente reflexión es impulsada por la constatación de que los trabajos que refieren las relaciones entre Iglesia y dictadura tratan mayoritariamente de las acciones de padres y obispos, dejando a las religiosas un papel secundario y raramente detallado. Por tanto, nos dedicamos específicamente a la observación de la forma cómo tal participación fue retratada por los periódicos impresos de gran circulación durante el período en cuestión. Dando prioridad a los reportajes publicados en los años 1967 y 1968, nuestra idea es problematizar la participación efectiva de religiosas en marchas y manifestaciones, así como el espacio de esta participación en la historiografía contemporánea. Este artículo se respalda en las discusiones de Jacques Semelin sobre la noción de resistencia y en la categoría de género.

Palabras clave: vida religiosa femenina; monjas; Iglesia Católica; marchas; dictadura.

A defesa das instituições democráticas e o direito à livre expressão são temas cuja relevância e atualidade marcam significativamente o Brasil após o processo de redemocratização. A insistência em abordar historiograficamente esses debates justifica-se, dentre outros motivos, pela necessidade de compreender os processos e eventos que conformam nosso passado recente e, assim, nosso presente. A empreitada torna-se particularmente desafiadora e fundamental quando assistimos à emergência de disputas (discursivas e políticas) acerca dos sentidos atribuídos a esses mesmos eventos, os quais subsidiam projetos de políticas públicas, de escolarização e, mesmo, uma sorte de tentativa de imposição/consolidação de memórias coletivas. Acreditando que as relaçôes entre política e religião fazem parte destes arranjos (políticos e discursivos), nos dedicaremos, nas páginas a seguir, a apresentar (re) consideraçôes a respeito das relaçôes entre a Igreja Católica e os movimentos de resistência e oposiçâo à ditadura civil-militar ${ }^{2}$ no Brasil.

\footnotetext{
${ }^{2}$ A opção pela designação "ditadura civil-militar" vincula-se a uma série de estudos que objetivam desconstruir o caráter exclusivamente militar atribuído ao governo ditatorial, evidenciando igualmente a participação e o apoio de parcelas da sociedade civil. A esse respeito, ver FICO, 2004.
} 
Podemos afirmar que tais relaçôes são consistentemente exploradas por uma historiografia recente, que ressalta desde o apoio institucional da Igreja ao golpe de 1964, chamado à época de Revoluçáo, até a importante participação de padres e bispos nas lutas pelos direitos humanos, contra a prática das torturas e a exacerbação da violência pelo regime. Tais trabalhos, todavia, pouco tratam da participaçáo de mulheres e, menos ainda, de religiosas. Quando citadas, normalmente, aparecem como coadjuvantes, sendo comum encontrarmos um significativo silêncio a respeito de suas açôes. Diante de tais constataçôes, o objetivo deste artigo é enfatizar a presença de freiras em movimentos de contestação pública a determinadas práticas promovidas pelo governo militar, entre 1964 e 1969, a partir da imprensa e, simultaneamente, ponderar a respeito do incipiente espaço atribuído a elas na historiografia recente.

\section{Igreja Católica e heterogeneidades: freiras no espaço público}

Pensando em termos institucionais, a Igreja Católica traz, ao largo de sua pervivência, a marca de disputas, conchavos, transformaçôes, violências, imposiçóes, hierarquias e heterogeneidades. Estas fazem-se igualmente visíveis na segunda metade do século XX. É possível perceber que, ao longo dos anos 1960, a participação e o posicionamento de religiosos e religiosas muitas vezes transcendia as questôes espirituais, situando-se no campo político, seja no apoio ou na oposição ao regime instaurado a partir de 1964. É importante ressaltar que as açóes de religiosos e religiosas nem sempre acompanhavam os posicionamentos declarados pela oficialidade católica, através de seu órgão de representação: a Confederaçáo Nacional dos Bispos do Brasil ${ }^{3}$. Ainda que, em princípio, a Igreja Católica tenha institucionalmente encampado o discurso anticomunista que, entre outros, fora usado como legitimação do golpe de 1964, já nesse período observamos padres e freiras contrapondo tais orientaçóes. Tal constatação não significa uma incoerência ou insubordinação, mas dá visibilidade a este caráter heterogêneo que constitui a instituiçáo.

Essa heterogeneidade torna-se explícita na segunda metade da década de 1960. A partir da leitura de jornais e revistas, podemos observar o envolvimento ativo de freiras em diferentes momentos e movimentos que tomaram ruas e praças com o objetivo declarado de contestar determinadas práticas governamentais, consideradas deveras abusivas e/ou repressoras. Se, para Jacques Semelin (2013), a resistência se funda sobre uma escolha, uma decisão e uma vontade - a de resistir através de atos e partilhar a recusa - é esta postura resistente que observamos no apoio aos estudantes, na inconformaçáo perante a pobreza, na contestaçáo à prisão e expulsão de religiosos e, principalmente, na denúncia do abusivo uso de violência

\footnotetext{
${ }^{3}$ É necessário ressaltar que, para além da $\mathrm{CNBB}$, o órgão de representação dos religiosos e religiosas é a CRB - Conferência dos Religiosos do Brasil.
} 
pelas forças policiais. Estes foram alguns dos motivos que levaram as freiras às ruas na segunda metade da década de 1960.

No que tange ao universo cristáo, náo foram apenas as freiras que tomaram as ruas nos anos 1960. Padres, bispos, leigos, pastores e crentes de diferentes designaçóes participaram igualmente das passeatas e manifestaçôes. É preciso ressaltar, porém, que no caso das freiras a livre expressão e a presença no espaço público não eram elementos conformadores de sua condiçáo institucional. A freira não ocupa os mesmos espaços e não compartilha das mesmas funçôes que um padre. De acordo com Maria José Rosado (2018), pensando em termos interseccionais, as freiras podem ser consideradas ainda mais relegadas ao esquecimento (historiográfico) que algumas outras mulheres na medida em que jamais seriam esposas ou mães e, institucionalmente, sabe-se que o clero, corpo de funcionários eclesiásticos, é restrito aos homens. Elas são, assim, submetidas a uma série de normas e regras, mas não participam dos sínodos e das definiçóes mais significativas dentro da Igreja Católica. É preciso considerar tais especificidades institucionais e, particularmente, de gênero quando atentamos tanto às ausências historiográficas quanto ao tratamento dado pela imprensa da época à constatação do (improvável) envolvimento de freiras com passeatas e manifestaçôes públicas.

Ao articularmos esta reflexão à categoria de gênero, é valido ressaltar que esta remete à ideia de que as formas de se compreender aquilo que é considerado característico do masculino e do feminino possui historicidade, assim, o gênero pode ser compreendido como um elemento constitutivo das relaçôes sociais (SCOTT, 1990). Uma vez que sua definição envolve diferentes símbolos, conceitos, normas, políticas e instituiçóes, é nela que nos amparamos para analisar seus efeitos nas relações sociais. No caso das freiras, o espaço que (não) ocupam na Igreja Católica pode ser compreendido por meio de relaçôes de gênero, uma vez que o "ser mulher" foi diversas vezes utilizado como justificativa para recorrentes exclusóes e atribuiçôes. Acreditamos entâo, assim como a teóloga Ivone Gebara (2005, p. 99), que o gênero está relacionado às instituiçôes, estruturas e práticas que pautam nossas relaçôes sociais e de poder. A respeito da utilizaçâo da categoria de gênero no estudo das religióes, Ana Maria Bidegain afirma que:

[...] a incorporação da categoria de gênero, cruzada com as de classe e etnia, não só é útil para a elaboração da história das religióes, é também uma chave essencial para a compreensão da história invisível das mulheres nas religióes e suas relações com todas as formas de estruturação do poder (1996, p. 28).

Ao falarmos sobre as freiras, devemos considerar esses aspectos interseccionais, afinal ainda que assumam uma vida devota e consagrada à Igreja, suas identificaçôes de gênero, classe e etnia acabam por pautar suas açôes e posiçôes em uma Igreja que passava por transformaçôes. 
Nesse sentido, os anos de 1967 e 1968 tornam-se particularmente significativos. Ainda que a primeira referência que encontremos sobre a participação de freiras em passeatas contestatórias após a institucionalização do regime militar no Brasil refira-se ao ano de 1966, em um movimento encabeçado por donas de casa contra o aumento do custo de vida, é a partir dos movimentos de 1967 que essa participação ganha contornos efetivamente políticos.

Antes, porém, de tratarmos da participação de religiosas em passeatas e manifestaçôes, é relevante lembrar que a Lei de Segurança Nacional, de março de 1967, em seu artigo 38 prevê a possibilidade de enquadramento da realização de "comício, reunião pública, desfile ou passeata" como propaganda subversiva. Até mesmo a manifestaçáo de solidariedade a esses atos era condenável, com pena que variava de seis meses a dois anos de prisão ${ }^{4}$. Em relação à lei, é necessário lembrar que ela não definia o que era efetivamente considerado subversão. Ela descrevia os atos que podiam ser criminalizados quando realizados com objetivo subversor. A indefinição, no entanto, fazia com que o reconhecimento do objetivo fosse um exercício interpretativo e subjetivo, o que tornava deveras difícil a possibilidade de defesa ou negação de determinadas acusaçóes.

A instauração da lei, todavia, não foi suficiente para cercear o envolvimento de religiosos e religiosas com as mobilizaçôes estudantis que eclodiam e que foram, muitas vezes, criminalizadas. "Expectativas em torno do Congresso da UNE" foi a manchete publicada pelo Diário de Notícias de 27 de julho de $1967^{5}$. Entre as expectativas anunciadas está o aumento da vigilância em conventos de padres e freiras, em vista do que ocorrera em Belo Horizonte no ano anterior. ${ }^{6}$ O Correio da Manhä, de 28 de julho de 1967, também noticiou o aumento da vigilância nos conventos e acrescenta a existência de "ordens para prender, sem distinção, qualquer pessoa que entrar nesses locais na data prevista para a realização do Congresso, mesmo que sejam padres ou freiras"'. Na quarta-feira, 2 de agosto de 1967, o Correio da Manhã retornou ao assunto anunciando a prisáo de padres e freiras que teriam protegido os estudantes durante a realização do $29^{\circ}$ Congresso da UNE, realizado em Vinhedo, no interior de São Paulo, em local cedido por setores progressistas da Igreja (RIDENTI, 1993). A esse respeito, além das reportagens citadas, é possível observar comentários bastante sarcásticos:

\footnotetext{
${ }^{4} \mathrm{Na}$ Lei de Segurança Nacional de 1969 a referência às passeatas, comícios e desfiles como propagandas subversivas são previstas no artigo 45, e o tempo de reclusão aumenta para entre um e três anos.

${ }^{5}$ Diário de Notícias. "Expectativas em torno do Congresso da UNE", 27 jul. 1967, p. 11.

${ }^{6}$ Em julho de 1966, as monjas beneditinas do Mosteiro Nossa Senhora das Graças colocaram o convento à disposição para alojar universitárias de outros estados que, eventualmente, viessem ao $28^{\circ}$ Congresso Nacional dos Estudantes. A decisão das freiras, que viviam em regime de clausura completa, foi antecedida pela dos padres dominicanos que ofereceram igualmente abrigo aos congressistas. A realização do congresso havia sido proibida e após sua instalaçáo foi realizado cerco militar nos conventos dos padres dominicanos e das freiras beneditinas.
}

${ }^{7}$ Correio da Manhã. "UNE”, 28 jul. 1967, p. 1. 
Polícia prendeu nove padres e algumas freiras. Aquilo já nem é mais Dops: é um Concílio Ecumênico.

Polícia prendeu nove sacerdotes! Será que não dava para pender um bandido mascarado? Um só?

Nove horas da manhã, tinha cinco mil pessoas estufando o corredor da polícia. É que a turma viu passar os padres, foi atrás: pensavam que era procissão. ${ }^{8}$

Em 3 de agosto de 1967 vários jornais noticiaram que o Dops iria liberar os presos. Questionadas sobre a realização do $29^{\circ}$ Congresso, as freiras entrevistadas, ambas estrangeiras (e, na verdade, missionárias leigas, como descobrir-se-ia depois), afirmaram que nada no comportamento dos jovens levaram à desconfiança do teor embativo do encontro. De qualquer forma, o fato de serem estrangeiras dificultaria o reconhecimento de inclinaçóes políticas. Alguns dos padres detidos, também estrangeiros, afirmaram pensar "tratar-se de um congresso estudantil normal". 9 O desconhecimento assumido por parte dos religiosos e religiosas nos causa certa inquietação na medida em que, semanas antes da realização do congresso, várias notícias foram veiculadas a respeito da mobilização do Dops para descobrir a sede do encontro, outras tantas ressaltavam que conventos de padres e freiras estavam sob vigilância em função da grande reunião estudantil e, finalmente, a realização do congresso havia sido efetivamente proibida. Ainda que esses religiosos e religiosas dedicassem mais tempo às questôes da alma que do corpo e que a política nacional náo estivesse no centro de suas atenções, as tensôes e conturbações do período foram amplamente divulgadas, chegando, certamente, ao conhecimento de amigos e familiares.

Nossa "desconfiança" da absoluta ingenuidade e desconhecimento dos religiosos e religiosas a respeito do teor do congresso é intensificada pelo fato de que, no ano seguinte, padres e freiras voltariam a apoiar, de forma ainda mais veemente, o movimento estudantil, especialmente através da Passeata dos Cem Mil. Todavia, como os eventos futuros eram evidentemente inacessíveis aos jornalistas e redatores, algumas manchetes veiculadas no mesmo dia afirmavam que os beneditinos, inocentes, haviam sido enganados pelos estudantes. ${ }^{10}$ Independentemente da polêmica participação, interessa-nos notar, por intermédio do depoimento de Frei André, superior dos dominicanos em Belo Horizonte, que as relaçóes entre alguns setores da Igreja e o governo era, já em 1967, marcada por animosidades. Segundo o frei, "a prisão de padres e freiras em São Paulo é mais uma demonstração de força e violência do governo. Tudo isto se enquadra perfeitamente dentro da linha de conduta até agora adotada pelos chefes militares". ${ }^{11}$

\footnotetext{
${ }^{8}$ Última Hora. "Ora, bolas", 3 ago. 1967, s/p.

${ }^{9}$ Diário da Noite. "Dops vai soltar padres e estudantes", 3 ago. 1967, p. s/p.

${ }^{10}$ Folha de São Paulo. "Beneditinos: fomos enganados", 3 ago. 1967, p. 14.

${ }^{11}$ Última Hora. "Superior dominicano não estranha invasão", 3 ago. 1967, s/p.
} 
Se 1967 foi um ano de tensóes para as religiosas que, de alguma maneira, envolveram-se em atividades que contrapunham as normas estabelecidas (pelo governo e, em certa medida, pela autoridade institucional da Igreja), estas certamente foram intensificadas em 1968. De acordo com Antunes e Ridenti:

O ano de 1968 teve início no Brasil com a eclosão de várias manifestaçóes de estudantes. Eles reivindicavam ensino público e gratuito para todos, uma reforma que democratizasse o ensino superior e melhorasse sua qualidade, com maior participação estudantil nas decisóes, mais verbas para pesquisa - voltada para resolver os problemas econômicos e sociais do Brasil. Os estudantes também contestavam a ditadura implantada com o golpe de 1964 e o cerceamento às liberdades democráticas (ANTUNES; RIDENTI, 2007, p. 78-89).

O ano de 1968 é certamente emblemático. Ainda que a polícia estivesse reprimindo manifestaçóes estudantis desde 1966, a morte de Edson Luis de Lima Souto no restaurante Calabouço pode ser considerada uma efeméride ${ }^{12}$. A notícia da morte do jovem percorreu o país causando comoção e inúmeras manifestaçóes. Sessenta mil pessoas teriam acompanhado o caixão mortuário do jovem, na tarde do dia seguinte, segundo Jacob Gorender (1998). Jornais como o Correio da Manhã noticiaram a realização de várias missas em homenagem ao estudante e, igualmente, a reação truculenta da polícia diante delas. Como exemplo, citamos a reportagem "Polícia volta a bater em Minas", que utiliza textualmente o termo "massacre" para se referir à investida policial contra aqueles que se fizeram presentes na missa de sétimo dia, realizada na Igreja de São José, em Belo Horizonte. ${ }^{13}$

No dia seguinte, os jornais já anunciam reaçóes. Em 6 de abril de 1968, a reportagem "Padres condenam as violências e vão aos cárceres ver presos" ${ }^{14}$ trata do posicionamento de 16 freiras que, assim como os padres, assinaram um manifesto exigindo que "a violência seja substituída pelo diálogo, a arbitrariedade pela justiça e a imposição pela liderança”. Além disso, as freiras também compunham a comissão de religiosos e estudantes que reivindicavam o direito de prestar assistência aos que foram encarcerados durante o conflito após a missa, conforme publicado pela Folha de São Paulo, em 8 de abril de 1968. ${ }^{15}$

No dia 25 de junho, as manifestaçóes estudantis e o apoio de religiosos e religiosas voltaram a figurar nas páginas de jornais. Conforme o Jornal do Brasil, cerca de " 500 pro-

${ }^{12} \mathrm{O}$ dia 28 de março, porém, marca acontecimento peculiar. O restaurante Calabouço, localizado no centro do Rio de Janeiro, foi palco de um conflito que resultou na morte do estudante Edson Luís de Lima Souto. A alegação para a invasão do restaurante pela polícia militar, em 28 de março de 1968, foi a possível preparação de uma passeata que atacaria a embaixada dos Estados Unidos. O uso de armas de fogo por parte dos policiais feriu vários jovens que se encontravam no local e, entre estes, Edson Luís.

${ }^{13}$ Correio da Manhã. "Polícia volta a bater em Minas", 5 abr. 1968, p. 5.

${ }^{14}$ Correio da Manhã. "Padres condenam as violências e vão aos cárceres ver presos", 6 abr. 1968, p. 1.

${ }^{15}$ Folha de São Paulo. "Situação estudantil é calma; bispo apela a Costa e Silva", 8 abr. 1968, p. 4. 
fessores, padres, freiras e mães foram ao pátio do MEC para condenar a violência contra os estudantes"16. A concentração do dia 25 foi noticiada também pelo Diário de Notícias, que, em uma grande reportagem distribuída em várias páginas da edição, anunciava o contrariamento (sic) dos manifestantes a respeito da repressão e prisão de estudantes..$^{17} \mathrm{~A}$ capa trazia, sob o título "Jovens vão marchar com Deus", a imagem de freiras, caracterizadas pelo uso do véu, em meio à multidão.

A utilização dessas imagens chama-nos particularmente a atenção. Sua escolha e a disposição das reportagens em uma página de jornal nunca são ocasionais, mas, sim, marcadas por um projeto editorial e, portanto, por intencionalidades. Apresentar as freiras em um espaço absolutamente atípico a elas materializava, de alguma maneira, o caráter atípico dos próprios eventos que eram relatados. $\mathrm{O}$ fato de as fotografias apresentarem freiras que trajavam o hábito religioso acentuava ainda mais esse caráter de deslocamento na medida em que o hábito poderia ser considerado representativo de uma vida religiosa apegada a valores mais "tradicionais" e, portanto, menos progressistas. É válido lembrar que, em termos institucionais, os anos 1960 foram marcados por uma série de mudanças na Igreja Católica - motivadas e/ou implementadas pela realização do Concílio Vaticano II. Dentre essas mudanças, a possibilidade de abandono do hábito religioso foi tema amplamente debatido. Ao mesmo tempo em que sua substituição por trajes civis era incentivada com o objetivo de incitar uma maior aproximação entre os religiosos, religiosas e o chamado "povo de Deus", alguns setores reprovavam tal possibilidade por considerar que o hábito representava os princípios e sentidos de uma vida consagrada. Esse debate transcendeu os muros dos conventos e seminários, ganhando espaço e atenção, inclusive, em jornais e revistas. ${ }^{18}$

Dessa maneira, se a presença de freiras em passeatas poderia parecer fora de lugar, tal percepção era intensificada por serem freiras trajando os hábitos e, portanto, justamente aquelas cujas congregaçóes não teriam aderido imediatamente aos encaminhamentos possibilitados pelo Concílio. Por outro lado, é preciso considerar igualmente que o hábito era o signo que tornava possível o reconhecimento e a identificaçáo de que as religiosas estavam presentes no movimento. Era, nessa ocasião, uma marca de distinçấo que poderia assumir um propósito político diferente daquele que seria "óbvio" ou "evidente". Eis porque não se pode definir posicionamentos progressistas e conservadores dentre as religiosas - e os religiosos - apenas pela presença ou ausência das vestes.

Em 26 de junho de 1968 foi realizada a Marcha da Família com Deus, pela Liberdade e Contra a Opressão, popularmente conhecida como a Passeata dos Cem Mil. Antes mesmo da passeata, as polêmicas a respeito do que poderia acontecer já pululavam nas páginas de

\footnotetext{
${ }^{16}$ Jornal do Brasil, 26 jun. 1968, p. 1.

${ }^{17}$ Diário de Notícias, 26 jun. 1968, p. $2-7$ e 13.

${ }^{18}$ Para uma reflexão detalhada a respeito das significaçôes do hábito religioso e dos debates acima citados, ver CUBAS, 2018.
} 
jornais. A possibilidade de repressão policial e a participação oficial do clero, das freiras, dos padres, de pais, mães e professores foram fortemente ressaltadas. ${ }^{19}$ Segundo a nota publicada em $O$ Estado de São Paulo, a Madre Superiora do Colégio de Sion, irmã Maria Alda, e numerosas outras freiras já haviam confirmado presença no movimento que, nas palavras do padre Vicente Adamo, tinha "características evangélicas e ao mesmo tempo reafirma seus pontos de vista de justiça e respeito pela dignidade humana". ${ }^{20}$

No dia seguinte à realização da Marcha, a presença das religiosas e dos religiosos é novamente enfatizada em reportagens e imagens pelos principais jornais do país. Detalhes sobre a presença de padres e freiras foram descritos pelo Correio da Manhã, na reportagem "Igreja nas ruas apoia a juventude". ${ }^{21}$ De acordo com o jornal, "ainda na concentração padres e freiras náo se distinguiram do resto dos manifestantes, aplaudindo com entusiasmo os discursos e as reivindicaçóes e proclamando, a toda hora, um respeito muito grande pelas lideranças jovens". Continua descrevendo que "logo depois dos padres vinha o protesto das freiras, vicentinas, ursulinas, irmãs de caridade e marianas" e que "padres e freiras dividiam seus slogans para descansar a voz. As frases mais repetidas durante o trajeto foram: os alunos têm razão, a Igreja é do povo, a Igreja quer justiça, Brasil dos brasileiros, chega de omissão: participação, liberdade para os presos". Em determinado momento da passeata, ao perceber que um repórter fazia anotaçôes enquanto jovens padres gritavam "liberdade pede a Igreja e a Igreja é contra a ditadura", uma freira explicou que a Igreja "não tem compromisso preconceituoso com ninguém, só com o homem e Deus fez o homem livre". Durante os discursos, no momento em que o padre João Batista, professor e porta-voz da Igreja no movimento, tomou a palavra, uma freira vicentina - cujo nome não aparece na reportagem - perante o nervosismo de seus colegas a respeito das futuras palavras do padre João afirmou: "vai falar bem sim, a causa é boa".

Referências escritas e visuais a respeito da participação das freiras na passeata foram trazidas igualmente pelo Diário de Notícias. Na reportagem "Sem repressão há ordem", encontramos inúmeras referências à presença ativa das religiosas. Já na capa da edição de 27 de junho encontramos a imagem de várias freiras, trajando hábitos religiosos, com a seguinte legenda: "Freiras de todas as ordens desfilaram de braços dados com as mães, numa demonstração inequívoca de que o Clero apoia os estudantes em sua luta". ${ }^{22}$

Na página 13 desta mesma edição encontramos a seguinte consideração: "O líder estudantil Vladimir Palmeira, que já está com prisão preventiva decretada, recebeu verdadeira ovação ao chegar para assumir a liderança de todo o movimento. Também recebeu demorados aplausos de um grupo de freiras, ao se incorporar aos estudantes". Ovacionadas foram também as freiras, quando chegaram para prestar seu apoio aos estudantes, segundo a le-

\footnotetext{
${ }^{19}$ Folha de São Paulo. "Polícia da Guanabara prepara a repressão", 25 jun. 1968, p. 12, e Jornal do Brasil. "Clero e professores saem hoje e estudantes amanhâ", 25 jun. 1968, p. 1.

${ }^{20}$ O Estado de São Paulo. "Clero sai hoje no Rio com estudantes”, 26 jun. 1968, s/p.

${ }^{21}$ Correio da Manhã. "Igreja nas ruas apoia a juventude", 27 jun. 1968, p. 15.

${ }^{22}$ Diário de Notícias. "Sem repressão há ordem”, 27 jun. 1968, p. 3.
} 
genda de uma foto publicada na mesma edição: "Várias freiras compareceram para hipotecar solidariedade aos estudantes. Foram recebidas com verdadeira ovação”.

É importante ressaltar que, ainda que os jornais destaquem a participação ativa de freiras nessas passeatas e mobilizaçóes, isso não nos possibilita indicar congregaçôes religiosas que, enquanto um coletivo institucional, seriam mais ou menos engajadas, a exemplo do que ocorreu com os frades dominicanos do Convento das Perdizes, em São Paulo. ${ }^{23}$ É preciso atentar aqui à própria estrutura das congregaçôes religiosas femininas, formadas comumente por diferentes comunidades, localizadas em diferentes cidades, estados ou países. Uma mesma congregação poderia possuir grupos que desempenhavam trabalhos com forte vinculação social, e outros não. A participação das freiras nas passeatas e a presença delas nos espaços públicos não pode ser explicada - ou reduzida - pela congregação à qual pertenciam. As congregações, assim como a própria Igreja Católica, são instituiçôes marcadas por tensôes, desacordos e heterogeneidade. ${ }^{24}$

Nem todos os comentários, porém, ressaltavam o entusiasmo e a aprovação da participação das religiosas e religiosos nas manifestaçôes. O ministro da Justiça, por exemplo, "lamentou que se tivesse permitido a queima de uma bandeira dos Estados Unidos, assim como a exibição de faixas com dizeres ofensivos ao governo, inclusive nas mãos de padres e freiras" ${ }^{25}$.

A participação das freiras foi igualmente registrada pelo Jornal do Brasil. A reportagem "Passeata dos estudantes reuniu 60 mil pessoas" descreveu, a exemplo dos outros jornais, acontecimentos relativos à marcha. Entre as faixas retratadas, uma com os dizeres "Fazer calar os moços é violentar nossa consciência" era empunhada por um padre e uma freira. ${ }^{26}$ O Jornal do Brasil ressaltou também o momento em que, após o discurso de Vladimir Palmeira, quando se anunciou a presença do representante do clero, um grupo de padres e freiras se levantou no meio da multidão e foi aplaudido pelos manifestantes. Sobre a ordem dos grupos na passeata, o jornal explica que o clero se apresentou em dois grupos distintos: o primeiro, logo após o grupo de intelectuais e representantes de universidades, contava com a presença do vigário-geral do Rio de Janeiro, Dom José de Carlos Pinto e com um grupo de freiras que, segundo a reportagem, pareciam assustadas. O principal slogan desse grupo era "A Igreja quer justiça". O segundo grupo do clero, mais numeroso, portava a faixa "Clero e povo com os estudantes" e era composto por padres e freiras que, segundo a imagem e legenda, estavam mais entusiasmados: "A ala das freiras mais jovens era a mais entusiasmada e acompanhava em coro a multidão". Outras cidades do Brasil, como Fortaleza, Recife e

\footnotetext{
${ }^{23}$ Além das reportagens publicadas na época, o engajamento de um grupo politizado de seminaristas e frades do convento dominicano localizado no bairro das Perdizes, em SP, tornou-se célebre devido, entre outros, aos registros realizados por Frei Betto e publicados nos livros Cartas da prisão (1977) e Batismo de sangue (2000). A esse respeito conferir FREIRE; SYDOW, 2017.

${ }^{24}$ Um exemplo dessa heterogeneidade característica da vida religiosa em uma congregação feminina pode ser observado em CUBAS, 2010 e CUBAS, 2008.

${ }^{25} \mathrm{O}$ mesmo depoimento foi publicado pelo Correio da Manhã, na mesma data.

${ }^{26}$ Jornal do Brasil. "Passeata dos estudantes reuniu 60 mil pessoas", 27 jun. 1968, p. 19.
} 
São Paulo, por exemplo, também organizaram passeatas de apoio aos estudantes e contaram igualmente com o apoio do clero e de freiras, sempre ressaltado nas reportagens.

As reportagens referenciadas explicitam e enfatizam a presença de religiosos e religiosas em movimentos que, dada a conjuntura e a motivação, podem ser facilmente identificados como políticos. A participação dos religiosos nessas atividades não é, absolutamente, um fato desconhecido. Chama-nos a atenção, porém, que mesmo que os jornais explicitem a presença das religiosas, pouco se trata destas em termos historiográficos. É importante ressaltar que, ainda que figurem lado a lado nos jornais, a presença dos religiosos náo pode ser interpretada pelas mesmas chaves analíticas que a presença das religiosas. A mera presença no espaço público, empunhando faixas e concedendo entrevistas conforma experiências distintas para padres e freiras. Tais experiências foram constituídas, dentre outras questóes, por incontornáveis relaçôes de gênero. Tomar a palavra e falar, de forma contestatória, em nome da Igreja, são atos que ganham significados absolutamente distintos, quando exercidos por padres e bispos ou por freiras. A análise da divulgação e visibilidade atribuída a esses atos, da participação de religiosos e religiosas neles, deve, portanto, considerar as relaçóes de gênero em seus exercícios interpretativos.

Ao compreendermos gênero, conforme as preleções de Joan Scott (2012), como um conjunto de regras sociais que tentam organizar as relaçóes de homens e mulheres na sociedade, a atuação das freiras nos parece, hoje, duplamente progressista, na medida em que ganhava destaque não apenas pelo conteúdo de suas reivindicaçóes, mas igualmente pela forma como as realizavam. Nossa leitura é norteada, assim, por alguns questionamentos propostos por Scott, os quais nos convidam a pensar as conexóes existentes entre gênero e política e, igualmente, atentar à maneira como as diferenças sexuais foram invocadas distintamente em movimentos políticos e sociais (SCOTT, 2012, p. 93). Conforme anteriormente indicado, as questôes de gênero são aqui intensificadas pelos sentidos que assumem quando articuladas ao universo religioso católico. Tal percepção é possibilitada, evidentemente, por uma concepção de política que não restringe suas fronteiras a eventos delimitados, mas relaciona-a à conformação de realidades coletivamente construídas (RÉMOND, 2003). Em um significativo trabalho sobre a vida religiosa feminina em meios populares, desenvolvido na década de 1980, com as fontes disponíveis então, por Maria José Rosado Nunes, encontramos inclusive a afirmação de que as "condições específicas da vida religiosa feminina impediram que as freiras tivessem participação política consciente nos acontecimentos vividos pelo país, a partir de 1964" (NUNES, 1985). O trabalho de Nunes foi embasado em literatura específica direcionada à vida religiosa feminina. Nessa literatura encontrou-se um absoluto silêncio a respeito das questóes políticas. Por outro lado, o cruzamento desse silêncio interno das congregaçóes com o que foi noticiado pelos jornais nos mostra que, se a participação política das religiosas não era institucionalmente motivada, isso não significa, porém, que era inexistente. 
Voltando aos jornais, as movimentaçôes do dia 26 repercutiram e chamaram a atenção para outras manifestaçóes por parte de membros da Igreja que apresentavam teor oposicionista. Em 4 de julho de 1968, o dominicano Frei Chico foi fortemente aplaudido por "freiras, padres, estudantes e operários quando fez um relato sobre a posição da Igreja no mundo, afirmando que ela, atualmente, é contra toda forma de imperialismo, seja econômico, político ou cultural". ${ }^{27} \mathrm{Nem}$ todas as manifestações expressavam, porém, entusiasmo. Dom Antônio Batista Fragoso, por exemplo, apesar de ser considerado um progressista dentro da Igreja, fez "restriçôes à participação do clero nos movimentos de rua, principalmente quando eles são de cunho essencialmente político, defendendo a presença de padres e freiras somente em passeatas que representassem uma forma de pressão contra uma determinada situação". ${ }^{28}$

Em 24 de julho de 1968, o Correio da Manhã publicou uma pequena nota sob o título "Freira está com a ação estudantil e a nova geração". Nesta, reproduz declaraçôes da irmã Armínia Escobar, considerada uma "freira muito pra frente", na VIII Assembleia Geral da Conferência dos Religiosos do Brasil. Irmã Armínia, segundo suas palavras, se considerava "partidária da juventude, dos cabeludos e da minissaia". Justifica seu posicionamento questionando "por que não havemos de lutar por melhores condiçôes de educação; maiores dotaçôes de verbas para as universidades, especialmente as do Nordeste, tâo esquecidas?" ${ }^{29}$

A VIII Assembleia Geral da Conferência dos Religiosos do Brasil (CRB) aconteceu simultaneamente à Assembleia Geral dos Bispos do Brasil e possibilitou manifestaçóes que demarcavam o posicionamento de religiosos e religiosas em relação aos rumos do país. Em 23 de julho de 1968, o Jornal do Brasil publica na íntegra a primeira versão do documento a ser estudado e modificado durante a Assembleia. A reportagem "Religiosos olham a fundo problemas da Igreja no país" faz referência à participação de 550 superiores de ordens, congregaçóes e institutos que representam mais de 60 mil frades e freiras no Brasil. Nessa assembleia, de acordo com o Jornal do Brasil, a CRB se coloca como uma força autônoma, independente dos bispos e que busca uma participaçáo mais efetiva nas transformaçôes sociais do país. ${ }^{30}$

Apesar de os religiosos, nas resoluçóes de sua Assembleia, não expressarem uma posição política institucional, o presidente da Confederação Latino-Americana dos Religiosos, padre Manuel Edwards, afirmou que as posiçóes das ordens religiosas deverão repercutir na ordem política vigente. Essa falta de um posicionamento político efetivo é relativizada por alguns depoimentos de religiosos, concedidos durante a realizaçáo da Assembleia. O abade de Salvador, D. Timóteo Amoroso Anastácio, por exemplo, defendeu a "pregação do Evangelho como um documento político". A diretora do Centro de Comunicaçóes Sociais da Faculdade de Filosofia de Recife, madre Armínia Escobar (a mesma que se posicionou a favor

\footnotetext{
${ }^{27}$ Diário de Notícias. "Igreja defende luta estudantil", 4 jul. 1968, p. 6.

${ }^{28}$ Diário de Notícias. "Igreja quer romper impasse indo ao encontro do governo", 26 out. 1968, p. 3.

${ }^{29}$ Correio da Manhã. "Freira está com a ação estudantil e a nova geração", 24 jul. 1968, p. 5.

${ }^{30}$ Jornal do Brasil. "Religiosos olham a fundo problemas da Igreja no país", 23 jul. 1968, p. 5.
} 
dos cabeludos e da minissaia) afirmou, expondo a situação do Nordeste, que "as indústrias não dão emprego, a agricultura não está sendo promovida como devia, doentes morrem de fome nos hospitais, somente o privilegiado ganha salário mínimo, faltando uma mentalidade de desenvolvimento". A respeito dos movimentos estudantis, madre Armínia afirmou que "como náo se desmontam ideias com armas, temos que achar outras armas morais para formar uma nova mentalidade". ${ }^{31}$ Em 27 de julho de 1968, o Correio da Manhã noticia o encerramento da Assembleia da CRB. Além das diferentes moções aprovadas sobre a atuação dos religiosos em relação ao analfabetismo e ao desenvolvimento da Amazônia, alguns depoimentos, como o da abadessa Luzia Ribeiro, marcaram a tônica dessa Assembleia ao afirmar que "a atuação do clero face à realidade brasileira deve prender-se à conscientização do povo". Além disso, afirmou a abadessa, "a situação da Igreja diante das questôes sociais e políticas deve ser desenvolvimentista". ${ }^{32}$

Em setembro do mesmo ano, observamos novamente as freiras envolvidas em manifestações de cunho político. Dessa vez, o elemento que impulsionou as mobilizaçóes foi a expulsão do padre francês Pierre Vauthier, que estava no Brasil desde 1963. Estabelecido na Vila Yolanda, onde vivia como um padre operário, trabalhava em turnos de 9 a 10 horas diárias e era associado ao Sindicato dos Metalúrgicos de Osasco. Foi preso durante uma greve em julho de 1968 e encaminhado ao Dops. No dia 28 de agosto foi noticiada sua expulsão do país. Ao tomarem conhecimento da expulsão, um grupo de 100 padres e freiras resolve organizar um protesto silencioso. Estabeleceram-se em frente à Catedral Metropolitana do Rio de Janeiro erguendo cartazes e distribuindo o panfleto "Por que estamos nas ruas". ${ }^{33} \mathrm{O}$ protesto mudo foi igualmente noticiado pelo Jornal do Brasil. Em "Padres em silêncio protestam contra a expulsão de Vauthier", encontramos a reprodução do documento entregue pelos padres e freiras aos manifestantes. Nele, lemos o seguinte:

O Governo apresentou tal motivo (a participação na greve de Osasco) porque não pode dizer a verdade. Mas nós, freiras e padres, também podemos dizê-la: a classe rica e os militares que as sustentam querem que a Igreja continue a seu serviço [...]. E quando veem que muitos padres e freiras já não aceitam a Igreja aliada aos que mantém a injustiça, a opressão e a miséria, a classe rica e os militares voltam-se contra as freiras e os padres que uniram-se ao povo. ${ }^{34}$

É explícito no documento acima reproduzido o teor político e assumidamente de oposição do movimento. Segundo a reportagem, os populares demonstravam surpresa perante a manifestação dos padres e freiras. Frases como "nossa luta é junto ao povo; fomos expulsos de nossa missão junto ao povo; expulsar padre operário é afastar Igreja do povo e Igreja com o povo custe o que custar" figuravam nos cartazes.

${ }^{31}$ O Estado de São Paulo. "Participação", 24 jul. 1968, s/p.

${ }^{32}$ Correio da Manhã. "Assembleia da CRB termina hoje com nova presidência”, 27 jul. 1968, s/p.

${ }^{33}$ Folha de São Paulo. "Protesto contra a expulsão do padre Vauthier", 5 set. 1968, s/p.

${ }^{34}$ Jornal do Brasil. "Padres em silêncio protestam contra a expulsão de Vauthier", 5 set. 1968, p. 7. 
A manifestação dos padres e freiras não apenas surpreendeu como gerou reprovaçôes. A nota "Riscos de omissão", publicada em 9 de setembro, no Jornal do Brasil, e uma coluna opinativa traziam sentenças como: "Ninguém pode dizer que religiosos sejam esquerdistas de convicçôes doutrinárias, mas o espetáculo era a canonização das técnicas comunistas mais ortodoxas incorporadas ao patrimônio das lutas de rua". ${ }^{35}$ Apesar do desagravo, nova manifestação foi organizada em Osasco, uma semana depois. Novamente encontramos padres e freiras empunhando frases e cartazes contra a expulsão do padre operário. Em uma das faixas, portadas pelos religiosos, saltava aos olhos a afirmaçáo de que "Cristo também sofreu pela Justiça". ${ }^{36}$

Como pudemos observar, a maior parte dos movimentos noticiados por jornais e que contaram com a participação efetiva de religiosas no ano de 1968 envolviam açôes de estudantes. Em outubro, novamente, os jornais trataram da realização de uma manifestação pública, na qual padres e freiras exigiam uma postura efetiva da $\mathrm{CNBB}$ no que concerne ao uso de violência, especialmente contra estudantes. A manifestação foi motivada pela forte repressão perpetrada por forças militares contra estudantes que participavam clandestinamente do XXX Congresso da UNE, em Ibiúna, sul de São Paulo. Após a prisáo de cerca de mil estudantes, cerca de 50 padres e freiras dirigiram-se ao Palácio Guanabara com a pretensão de entregar ao governador Negrão de Lima um memorial de repúdio às violências contra estudantes. ${ }^{37}$

Em dezembro, novas hostilidades entre membros da Igreja e o governo autoritário causaram reação por parte das religiosas. Segundo publicação de 9 de dezembro na Folha de São Paulo, três padres franceses e um diácono brasileiro foram presos em Belo Horizonte, acusados de subversão. ${ }^{38} \mathrm{~A}$ prisão dos padres causou novamente comoção entre os religiosos e religiosas. Perante tal ato, mais de mil religiosas reuniram-se para redigir um manifesto de solidariedade aos padres presos. A reuniáo foi amplamente noticiada entre os dias 10 e 12 de dezembro de 1968, sendo que o número de religiosas participantes variava de 1.000 a 1.500 , como podemos observar, por exemplo, no jornal Folha de São Paulo. Até mesmo religiosas enclausuradas deslocaram-se para participar de um encontro no Colégio Santa Maria, em Belo Horizonte, na presença do arcebispo Joáo Rezende Costa. ${ }^{39} \mathrm{Na}$ mensagem de convocação do encontro, as promotoras afirmaram que as freiras também são porção da Igreja e, assim, também deviam participar ativamente dos acontecimentos. ${ }^{40}$

\footnotetext{
${ }^{35}$ Jornal do Brasil, "Riscos de omissão", 8 set. 1968, p. 6.

${ }^{36}$ Jornal do Brasil. "Padres e freiras fazem passeata em Osasco contra a expulsão de Vauthier", 14 set. 1968, p. 16.

${ }^{37}$ Jornal do Brasil. "Padres e irmãs pediram a Dom Scherer que a CNBB afirme repúdio à violência", 25 out. $1968, \mathrm{~s} / \mathrm{p}$.

${ }^{38}$ Folha de São Paulo. "Amanhã no STM o habeas em favor dos padres presos", 9 dez. 1968, p. 4.

${ }^{39}$ Folha de São Paulo. "1.000 freiras manifestam-se sobre padres presos em BH", 12 jun. 1968, s/p.

${ }^{40}$ Folha de São Paulo. "Freiras fazem reunião", 10 dez. 1968, s/p.
} 
O documento final da reuniáo, redigido pela irmá Luzia Ribeiro de Oliveira, monja beneditina, superiora contemplativa da abadia Nossa Senhora das Graças (MG), esclarece logo de início que "o ser contemplativa não importaria numa alienação, afinal, as contemplativas estão presentes a todas as pulsôes da Igreja” ${ }^{\text {” }}$. Afirma, ao longo do texto, em relação ao grupo das religiosas, não poderem "eximir-se de uma participação mais ativa e consciente na procura do desenvolvimento integral do homem e de todos os homens". Diretamente a respeito das prisóes, a irmã afirma o seguinte:

Sentimos toda a imensa gravidade dos fatos dos últimos acontecimentos destes tempos conturbados, aqui, em nosso país, em nossa cidade. Corta-nos como espada a falta de sensibilidade com que se fazem repressóes às profundas ansiedades de uma crise mundial, agravada para nós pela situação de penúria sempre maior em que se debatem a maioria de nossos irmãos. Repressóes que se processam como se desconhecessem os direitos do homem e - como lembra a Declaração da CNBB de 10/12/68 - causam apreensão utilizando métodos de delação e execração pública de pessoas colocadas em incomunicabilidade, antes de qualquer conclusão sobre sua culpabilidade ou inocência. ${ }^{42}$

Ainda que o documento redigido pela religiosa não expresse uma crítica direta ao governo de então, é possível perceber seu alinhamento com o imperativo de uma ação diante de práticas consideradas desumanas e, portanto, reprováveis. Além disso, foi explicitado textualmente o alinhamento do posicionamento das irmãs com as conclusóes do documento da 2a Conferência Geral do Episcopado Latino-Americano, realizada em Medellín no mesmo ano. Nesta, apregoou-se fortemente a necessidade de libertação da injustiça e opressão. ${ }^{43}$ Mesmo que a CRB não tenha se posicionado oficialmente contrária ao regime político, sua ação previa a transformação das estruturas em conformidade com as interpretaçôes latino-americanas dos documentos do Concílio Vaticano II, realizado entre 1962 e 1965, e que previa a atualizaçáo da Igreja e uma maior aproximaçáo entre os religiosos e o povo e da já citada Conferência do CELAM, de Medellín, em 1968. Essa transformaçáo libertadora deveria partir do povo oprimido. Dessa forma, o papel dos religiosos e religiosas era a conscientização para que fosse dada ao povo a condição de buscar sua libertação.

${ }^{41}$ BIBLIOTHĖQUE DE DOCUMENTATION INTERNATIONALE CONTEMPORAINE. Texto final da Reuniáo das Religiosas de Belo Horizonte. Belo Horizonte. 11 dez. Fundo Charles Antoine/ DIAL - 1968/ BDIC.

${ }^{42}$ Idem.

${ }^{43}$ A 2a Conferência Geral do Episcopado Latino-Americano é considerada por Enrique Dussel (1989), filósofo argentino radicado no México, como o acontecimento fundamental da Igreja Latino-Americana no século XX. 


\section{Considerações finais}

Em 13 de dezembro de 1968 ocorreu, no Brasil, a promulgação do Ato Institucional n. 5. A partir de então, notícias a respeito da participação de religiosas em passeatas e manifestações públicas tornam-se cada vez mais escassas. Cada vez menos frequentes eram, igualmente, as próprias manifestações, e a implementação da censura, fechamento de jornais e, claro, o recrudescimento do regime ajudam-nos a entender tais ausências. Conforme Marcos Napolitano (2006), a ditadura militar, especialmente a partir do seu acirramento em 1968 e 1969, forçou uma introjeção no mundo cotidiano através do esvaziamento dos espaços tradicionais de expressão política, como o parlamento, o sindicato, a praça pública e a imprensa. Tal movimento afetou igualmente as possibilidades de açóes por parte dos religiosos e religiosas. $\mathrm{O}$ esvaziamento dos espaços tradicionais incita, todavia, à criação de outros.

As relaçôes entre a Igreja Católica e o regime foram bastante tensas durante toda a década de 1970. Ao mesmo tempo em que se mantiveram certas relações de coexistência (SERBIN, 2001), a resistência passa a se manifestar nos mais diferentes lugares. Ainda que as religiosas não tenham, como coletivo, pego em armas ou se posicionado publicamente contra o governo, foi, enquanto coletivo, que reconheceram a importância de uma atuaçáo junto ao povo, em nome das causas sociais que promovessem efetivamente uma sorte de "libertação". É bastante significativo, nesse sentido, o informe expedido pelo Serviço Nacional de Informaçôes que trazia como assunto: "aliciamento subversivo por parte de freira" ${ }^{\text {"4 }}$. O documento, datado de 1977, trata da ação suspeita de freiras estrangeiras que realizavam reuniôes na capela de um colégio, em Sáo Paulo, promovendo o Movimento do Custo de Vida. Esse movimento obteve apoio significativo dos setores progressistas da Igreja Católica e de outros movimentos, tais como a Frente Nacional do Trabalho, o Movimento Feminino da Anistia, entre outros. Segundo o informe, as religiosas, durante suas reuniōes, teriam afirmado que "tudo era válido para a melhoria das condiçóes dos pobres, até mesmo o sequestro do Presidente da República”45.

No caso das religiosas, suas açôes ocorriam não em púlpitos ou espaços de grande visibilidade, mas é possível entrevê-las em colégios, no abrigo aos perseguidos, nas denúncias e na luta pelas causas sociais. A ausência na historiografia e a presença nas ruas - e, consequentemente, nos jornais - durante o significativo ano de 1968 chama-nos a atenção para a necessidade de revisitar, reconhecer, repensar e reescrever narrativas a respeito do período em questão. A teóloga Ivone Gebara, em depoimento à Comissão Nacional da Verdade, em 2013, afirmou que "o que fala mais alto é o sentimento de muitos (as) de que há retificaçôes, há novas informaçóes que precisam ser dadas para sairmos de algumas armadilhas nas quais nossa história coletiva dos tempos da ditadura militar o Brasil caiu”. Acreditamos que

\footnotetext{
${ }^{44}$ FUNDO SNI. Memórias reveladas. BR DFANBSB V8.MIC, GNC.EEE.80004557.

${ }^{45}$ Idem, fl. 1.
} 
a participação de religiosas em movimentos de resistência e/ou oposição à ditadura militar no Brasil figure fortemente dentre essas necessárias retificaçóes. Nossa intenção neste artigo, assim, coincide com as preocupaçóes de Gebara a respeito das perniciosas consequências sociais do esquecimento.

\section{Fontes documentais}

BIBLIOTHẼQUE DE DOCUMENTATION INTERNATIONALE CONTEMPORAINE. Texto final da Reuniáo das Religiosas de Belo Horizonte. Belo Horizonte. 11 dez. Fundo Charles Antoine/ DIAL - 1968/ BDIC.

Correio da Manhã. "UNE”. Rio de Janeiro, 28 jul. 1967, p. 1.

Correio da Manhã. "Polícia volta a bater em Minas". Rio de Janeiro, 5 abr. 1968, p. 5.

Correio da Manhã. "Padres condenam as violências e vão aos cárceres ver presos". Rio de Janeiro, 6 abr. 1968, p. 1.

Correio da Manhã. "Igreja nas ruas apóia a juventude". Rio de Janeiro, 27 jun. 1968, p. 15.

Correio da Manhã. "Freira está com a ação estudantil e a nova geração". Rio de Janeiro, 24 jul. 1968, p. 5.

Correio da Manhã. "Assembléia da CRB termina hoje com nova presidência". Rio de Janeiro, 27 jul. 1968, s/p.

Diário da Noite. "Dops vai soltar padres e estudantes". Rio de Janeiro, 3 ago. 1967, s/p.

Diário de Notícias. "Expectativas em torno do Congresso da UNE". Rio de Janeiro, 27 jul. 1967, p. 11.

Diário de Notícias. Rio de Janeiro, 26 jun. 1968, p. 2-7 e 13.

Diário de Notícias. "Sem repressão há ordem". Rio de Janeiro, 27 jun. 1968, p. 3.

Diário de Notícias. "Igreja defende luta estudantil”. Rio de Janeiro, 4 jul. 1968, p. 6.

Diário de Notícias. "Igreja quer romper impasse indo ao encontro do governo". Rio de Janeiro, 26 out. 1968 , p. 3.

Folha de São Paulo. "Beneditinos: fomos enganados". São Paulo, 3 ago. 1967, p. 14.

Folha de São Paulo. "Situação estudantil é calma; bispo apela a Costa e Silva". São Paulo, 8 abr. 1968, p. 4.

Folha de São Paulo. "1.000 freiras manifestam-se sobre padres presos em BH". São Paulo, 12 jun. 1968, s/p.

Folha de São Paulo. "Polícia da Guanabara prepara a repressão". São Paulo, 25 jun. 1968, p. 12. Folha de São Paulo. "Protesto contra a expulsão do padre Vauthier". São Paulo, 5 set. 1968, s/p. 
Folha de São Paulo. "Amanhã no STM o habeas em favor dos padres presos". São Paulo, 9 dez. 1968, p. 4.

Folha de São Paulo. "Freiras fazem reuniáo". São Paulo, 10 dez. 1968, s/p.

FUNDO SNI. Memórias reveladas. BR DFANBSB V8.MIC, GNC.EEE.80004557. Disponível em: http://pesquisa.memoriasreveladas.gov.br/mrex/consulta/resultado_pesquisa_ new.asp?v_pesquisa=freira\&input_pesqfundocolecao=. Acesso em 15 dez. 2018.

Jornal do Brasil. "Clero e professores saem hoje e estudantes amanhã. Rio de Janeiro", 25 jun. 1968, p. 1.

Jornal do Brasil. Rio de Janeiro, 26 jun. 1968, p. 1.

Jornal do Brasil. "Passeata dos estudantes reuniu 60 mil pessoas". Rio de Janeiro, 27 jun. 1968, p. 19.

Jornal do Brasil. "Religiosos olham a fundo problemas da Igreja no país". Rio de Janeiro, 23 jul. 1968 , p. 5.

Jornal do Brasil. "Padres em silêncio protestam contra a expulsão de Vauthier". Rio de Janeiro, 5 set. 1968 , p. 7.

Jornal do Brasil. "Riscos de omissão". Rio de Janeiro, 8 set. 1968, p. 6.

Jornal do Brasil. "Padres e Freiras fazem passeata em Osasco contra a expulsão de Vauthier". Rio de Janeiro, 14 set. 1968, p. 16.

Jornal do Brasil. "Padres e irmãs pediram a Dom Scherer que a CNBB afirme repúdio à violência”. Rio de Janeiro, 25 out. 1968, p. s/n.

O Estado de São Paulo. "Clero sai hoje no rio com estudantes". São Paulo, 26 jun. 1968, s/p.

O Estado de São Paulo. "Participação". São Paulo, 24 jul. 1968, s/p.

Última Hora. "Ora, bolas". Rio de Janeiro, 3 ago. 1967, s/p.

Última Hora. "Superior dominicano não estranha invasão". Rio de Janeiro, 3 ago. 1967, s/p.

\section{Referências}

ANTUNES, Ricardo; RIDENTI, Marcelo. Operários e estudantes contra a ditadura: 1968 no Brasil. Mediaçóes, v. 12, n. 2, p. 78-89, 2007.

BIDEGAIN, Ana Maria. Gênero como categoria de análise na História das Religiōes. In: BIDEGAIN, Ana Maria (org.). Mulheres: autonomia e controle na América Latina. São Paulo/ Petrópolis: Vozes/ Cehila, 1996.

CUBAS, Caroline Jaques. Cartas de política, cartas de fé: inserção social e vida religiosa entre 1960 e 1990. Tempo, Niterói, v. 12, n. 24, p. 149-172, 2008. Disponível em: http:// 
dx.doi.org/10.1590/S1413-77042008000100008.

CUBAS, Caroline Jaques. Do hábito à resistência: freiras em tempos de ditadura militar no Brasil. Rio de Janeiro: Arquivo Nacional, 2018.

CUBAS, Caroline Jaques. Memórias de formação: sentidos e sensibilidades durante o início da vida religiosa na CIIC (1960-1990). Tempo e Argumento. Florianópolis, v. 2, n. 2, p. 4460, jul. / dez. 2010. Disponível em: http://www.revistas.udesc.br/index.php/tempo/article/ view/2175180302022010044.

DUSSEL, Enrique. História da Igreja latino-americana (1930-1985). São Paulo: Paulus, 1989.

FICO, Carlos. Versóes e controvérsias sobre 1964 e a ditadura militar. Revista Brasileira de História, v. 24, n. 47, 2004.

FREIRE, Américo; SYDOW, Evanize. Frei Betto: biografia. Rio de Janeiro: Civilização Brasileira, 2017.

GEBARA, Ivone. Corporeidade e gênero: uma perspectiva ecofeminista. In: SOCIEDADE DE TEOLOGIA E CIÊNCIAS DA RELIGIÃO. Corporeidade e teologia. São Paulo: Paulinas, 2005.

GORENDER, Jacob. Combate nas trevas. São Paulo: Editora Ática, 1998.

NAPOLITANO, Marcos. Cultura e poder no Brasil contemporâneo. Curitiba: Juruá Editora, 2006.

NUNES, Maria José Rosado. Vida religiosa nos meios populares. Petrópolis: Vozes, 1985.

RÉMOND, René. Por uma história politica. Rio de Janeiro: FGV, 2003.

RIDENTI, Marcelo. O fantasma da Revolução Brasileira. São Paulo: Editora da Unesp, 1993. ROSADO, Maria Jose. A história esquecida das mulheres. Prefácio. In: CUBAS, Caroline Jaques. Do hábito à resistência: freiras em tempos de ditadura militar no Brasil. Rio de Janeiro: Arquivo Nacional, 2018.

SCOTT, Joan W. Gênero: uma categoria útil de análise histórica. Educação e Realidade, v. 16, n. 2, Porto Alegre, jul./dez. 1990.

SCOTT, Joan. De l'utilité du genre. Paris: Fauard, 2012.

SEMELIN, Jacques. Sans armes face à Hitler. Paris: Les Arènes, 2013.

SERBIN, Kenneth. Diálogos na sombra: bispos e militares, tortura e justiça social na ditadura. São Paulo: Companhia das Letras, 2001. 